\title{
SEX HORMONES GENES EXPRESSION AND SEXUAL DYSFUNCTION ASSOCIATION AMONG MALE HEROIN ADDICTS AT ZAGAZIG UNIVERSITY HOSPITALS, EGYPT
}

\author{
Arwa A. El-Sheikh ${ }^{1}$, Dalia IA Mesallam ${ }^{1}$, Noha M Abedelsalam², Reem Allam ${ }^{3}$, Abdullah Saad \\ ${ }^{1}$ Forensic Medicine and Clinical Toxicology Department, Faculty of medicine, Zagazig university, \\ Egypt. \\ ${ }^{2}$ Public Health and Preventive Medicine Department, Faculty of medicine, Zagazig university, Egypt. \\ ${ }^{3}$ Clinical Pathology Department, Faculty of medicine, Zagazig university, Egypt. \\ ${ }^{4}$ Psychiatry Department, Faculty of medicine, Zagazig university, Egypt.
}

\begin{abstract}
Objectives: Drug addiction becomes one of the grave problems worldwide, which has much health adverse effects. There are many reports relating Sexual dysfunction to heroin addiction that also affecting sex hormones. The aim of this study was to investigate the association of sexual dysfunction, expression of sex hormones related genes and sex hormones disturbance with illicit heroin addiction in patients presented to psychiatric outpatient clinic, Zagazig University Hospitals, Egypt.

Methods: Semi-structured questionnaire and International index of erectile function scale were used for assessment of erectile and sexual dysfunction of 180 adult males (90 heroin addicts and 90 controls). Then the heroin addiction group was subdivided into (Initiation of heroin withdrawal group and 6-months follow up group, 45 individuals in each subgroup. Blood samples were collected for detection of sex hormones (Testosterone, FSH and LH) by Electrochmeiluminescence analyzer, genes expression of (Cytochrome 19 (CYP19), Follicle Stimulating Hormone related gene (FSH-B), Luteinizing Hormone related gene (LH-B) by Quantitative Real-time polymerase chain reaction(RT-PCR). Results: heroin addicts suffered from a matter of sexual dysfunction as (decrease erectile function, orgasm, sexual desire and intercourse satisfaction), reduction of serum sex hormones and up regulation of CYP19 gene, down regulation of FSH-B and LH-B genes. Conclusion: This study suggested that there is a correlation between heroin addiction and sexual dysfunction with reduction of sex hormones secondary to affection of sex hormone related genes that showed improvement in the group of heroin discontinuation for 6 months. It is recommended to increase the period of follow up of heroin addicts as complete improvement may occur.
\end{abstract}

Keywords: Heroin, addiction, sex hormones, genes expression,testosterone

\section{INTRODUCTION}

D rug addiction is a worldwide serious problem that affects various populations (National Institute of Drug Abuse, 2018). Illicit drugs are known to affect a person's sexual behavior and ability to function. Drugs abusers often take these substances as a means to escape from psychological or emotional problems or to ignore physical difficulties which are contributing to sexual dysfunction. They feel that their sexual performance improves after substance use. However, their partners often report the opposite (Nestler, 2015).

Heroin is diamorphine obtained from opium through a chemical process contain acetone and acetic anhydride, it is from the commonly used recreational drugs because of its euphoric action (Uchtenhagen, 2011). After absorption, it is deacetylated variously into the inactive 3monoacetylmorphine and the active 6monoacetylmorphine (6-MAM), and then to morphine, which bind to $\mu$-opioid receptors, resulting in the drug's euphoric, analgesic and anxiolytic effects (Langham et al., 2018). Heroin addiction is a known cause of sexual dysfunction. Many studies have reported higher rates (34-85\%)of sexual dysfunction in patients with heroin abuse than in the general population (Trajanovska et al., 2013).

It was demonstrated that heroin use reduces sexual interest, libido and potency. It may increase the duration of the male erection resulting in delayed ejaculation however, this 
soon changes as the drug begins to take hold of sexualdesires and sex. Heroin decreases the sex hormone levels in both humans and experimental animals (Cummins and Miller, 2003).

Sexual dysfunction may affect fertility as it covers a range of problems including erectile dysfunction (ED), premature or delayed ejaculation in men, pain associated with intercourse, low libido and poor response to sexual contact (Mehtry et al., 2013).

Sexual problems can cause major relationship and psychological problems if unresolved. So, the study aimed to investigate the association of sexual dysfunction, expression of sex hormones related genes and sex hormones disturbances with illicit heroin addiction in patients presented to psychiatric outpatient clinic, Zagazig University Hospitals, Egypt.

\section{Subjects}

\section{SUBJECTS AND METHODS}

This is a comparative cross sectional study that was conducted on consecutive heroin addict males who attended to psychiatric outpatient clinic at Zagazig University Hospitals from December 2016 to June 2017and had been diagnosed from history and morphine urine test. Inclusion criteria the study included 1- adult heroin addict males who attend psychiatric outpatient clinic to initiate treatment at the time of study, 2- adult heroin addict males who initiate treatment 6 months or more before conducting the study and under behavior therapy without medication and 3-Control group from relative of patients.

Exclusion criteria adult males abused substances other than heroin, addicts under opioid substitution treatments, patients with any health problems that affect sexual function, patients received treatment that affect sexual functions or medication used for treatment of sexual dysfunction were excluded.

Study design according to these exclusion criteria 180 adult male were enrolled in this study, divided into 2 groups (Control (I) and Heroin addiction groups) 90 individuals in each group. Then the heroin addiction group was subdivided into (Initiation of heroin withdrawal
group(II) and 6-months follow up group(III) 45 individuals in each subgroup. Blood samples were drawn for Gene expression analysis of (Cytochrome 19 (CYP19), Follicle Stimulating Hormone related gene (FSH-B), Luteinizing Hormone related gene (LH-B) and sex hormones assessment (Testosterone, FSH and LH).

\section{Methods}

Semi-structured questionnaire that included socio demographic data, Age and Heroin addiction history that included questions about (Mode of heroin addiction, the age of first heroin use, period of heroin abuse (years) and quantity of heroin abuse (gm/day). The questionnaires were conducted by the psychiatric physicians in outpatient clinic of addiction at Zagazig University Hospitals.

Sexual history assessment (International index of erectile function) (ILEF) it is a multidimensional scale for assessment of erectile and sexual dysfunction (Rosen et al.,1997). It covers 5 domains, each one included questions related to the past 4 weeks. The domains were as follow:

Erectile function domain included 6 items (questions), each item ranged 0-5 with maximum score 30 .

Orgasmic function domain included 2 items, each item ranged 0-5 with maximum score 10 .

Sexual desire domain included 2 items, each item ranged 0-5 with maximum score 10 .

Intercourse satisfaction domain included 3 items, each item ranged $0-5$ with maximum score 15.

Overall satisfaction domain included 2 items, each item ranged 0-5 with maximum score 10 .

\section{Hormonal assay}

Testosterone, FSH and LH were assayed from serum samples withdrawn from control and patient groups according manufacture structure by Electrochmeiluminescence on Cobas 6000 analyzer (E601 module).

Gene expression analysis

RNA isolation, cDNA preparation. Total RNA Purification kit (Jena Bioscience, Germany) was used to extract total RNA from EDTA peripheral blood samples after the 
manufacturer's protocol. The reverse transcription process was done by the SCRIPT Reverse Transcriptase kit (Jena Bioscience, Germany) producing first strand cDNA using Oligo (dT) primer and M-MLV RT enzyme. In ice, we mix $1.5 \mu \mathrm{l}$ RNase-free water, $10 \mu \mathrm{l}$ RNA template and $1 \mu$ l Oligo-(dT) primer together, then $4 \mu \mathrm{l}$ SCRIPT RT buffer, $1 \mu \mathrm{l}$ dNTP Mix, $1 \mu$ RNase inhibitor, $1 \mu 1$ Dithiothreitol stock solution and $0.5 \mu \mathrm{l}$ SCRIPT reverse transcriptase were added then incubated at $30^{\circ} \mathrm{C}$ for $10 \mathrm{~min}$ and $50^{\circ} \mathrm{C}$ for $60 \mathrm{~min}$. The cDNA was stored at $-20^{\circ} \mathrm{C}$ till analysis

(Livak,2001).

Quantitative Real-timepolymerase chain reaction(RT-PCR). Quantitative real-time RTPCR for cytochrome 19(CYP19), FSH-B and LH-B genes were performed on a Stratagene Mx3005P qPCR System (Agilent Technologies, Germany) using the qPCR GreenMaster (Jena Bioscience, Germany). PCR reaction with $20 \mu \mathrm{l}$ final volume was prepared by adding $10 \mu 1$ qPCR Green Master, $0.5 \mu$ forward primer (10 $\mu \mathrm{M}), 0.5 \mu \mathrm{l}$ reverse primer $(10 \mu \mathrm{M})$ (Table1), 5 $\mu l$ template cDNA and $4 \mu \mathrm{l}$ PCR grade water into realtime PCR wells. The cycling program was prepared as following $95^{\circ} \mathrm{C}$ for $10 \mathrm{~min}$, then 40 cycles $\left(95^{\circ} \mathrm{C}\right.$ for $15 \operatorname{secs}, 58^{\circ} \mathrm{C}$ for 1 min). The transcription levels of target genes were normalized to those of $\beta$-actin gene which used as reference gene. The normalized quantity of the target gene was obtained by subtracting cycle threshold (CT) for $\beta$-actin from the $\mathrm{CT}$ for the target gene ( $\triangle \mathrm{CT}$ sample). The same calculation was performed with controls ( $\Delta \mathrm{CT}$ control). Then $\Delta \Delta \mathrm{CT}$ was calculated as the difference of these values $(\Delta \Delta \mathrm{CT}=\Delta \mathrm{CT}$ sample $-\Delta \mathrm{CT}$ control). Finally, the relative expression was expressed as fold change by $2^{-\Delta \Delta C T}$ relative to control (Livak,2001).

Table 1. Primers Sequences

\begin{tabular}{|c|c|c|}
\hline & Forward primer & Reverse primer \\
\hline CYP19 & $\begin{array}{l}\text { 5'-ATA CCA GGT CCT GGC TAC } \\
\text { TG-3' }\end{array}$ & 5'-TTG TTG TTA AAT ATG ATG CC -3 \\
\hline FSH-B & $\begin{array}{l}\text { 5'-GGG CCA GGA ACT GTGAAA } \\
\text { TA-3' }\end{array}$ & 5'-TCT CAG AAC TGC CGA GGT TT-3' \\
\hline LH-B & $\begin{array}{l}\text { 5'-TCT CAC CACCAC CGT CTG } \\
\text { TA-3' }\end{array}$ & 5'-TGC AGT CGC TGT AGT CC ATC-3' \\
\hline$\beta$-actin & $\begin{array}{l}\text { 5'-TTG CCG ACA GGA TGC AGA } \\
\text { A-3' }\end{array}$ & 5'-GCC GAT CCA CAC GGAGTA CT-3' \\
\hline
\end{tabular}

\section{Pilot study}

A pilot study was conducted on 20 patients and validity test to the questionnaires was done for language clarity, content, relevancy, ease of understanding and time needed to answer. Reliability test was done by using the reliability coefficients (Cronbach's alpha) which was high for all questionnaires, and suitable for scientific purposes. The results of the pilot study showed no difference from the main results so it was included in the main results.

\section{STATISTICAL ANALYSIS}

Sample size was calculated using OpenEpi I program at a confidence interval $95 \%$ and power of test $80 \%$. After data collection, data were coded, entered and analyzed using SPSS (Statistical Package for Social Science) version 19. Quantitative data were presented by mean, standard deviation and standard error of mean. Student $t$ test was used for comparing data and The Pearson correlation coefficient (r) was used to examine the linear correlation between variables. $\mathrm{P}$ value $(\leq 0.05)$ was considered significant difference and $\mathrm{P}$ value $(\leq 0.01)$ was considered the highly significant difference (Craparo, 2007).

\section{RESULTS}

Semi-structured questionnaire The sample size showed 180 adult males where addiction group averaged (33.6 \pm 6.5$)$ years of age (range 
from 23-48) years, while control group averaged (32.8 \pm 6.2 ) years of age (range from 20-46) years of age with no statistical difference between them (Table 2).

Heroin addiction history inhalation route was the most common mode of addiction among addict group followed by injection and smoking of heroin in cigarettes (Figure 1). The mean age of first heroin use was $24.8 \pm 3.4$, while the mean period of use was $8.5 \pm 5.4$ years. The mean quantity of heroin was $1.0 \pm 0.7 \mathrm{gm} /$ day (Table 2).

Table 2. Mean age and addiction history of studied groups

\begin{tabular}{|c|c|}
\hline Age of the studied groups & $\mathbf{N}=180$ \\
\hline $\begin{array}{l}\text { Addict group }(\mathbf{N}=90) \\
\text { Range } \\
\text { Mean } \pm \text { SD } \\
\text { Control group }(\mathbf{N = 9 0}) \\
\text { Range } \\
\text { Mean } \pm \text { SD } \\
P \text { value }\end{array}$ & $\begin{array}{c}23-48 \\
33.6 \pm 6.5 \\
\\
20-46 \\
32.8 \pm 6.2 \\
0.4 \\
\end{array}$ \\
\hline Addiction history & $\mathbf{N}=90$ \\
\hline $\begin{array}{l}\text { Age of first heroin use (years) } \\
\text { Range } \\
\text { Mean } \pm \text { SD } \\
\text { Period of heroin abuse(years) } \\
\text { Range } \\
\text { Mean } \pm \text { SD } \\
\text { Quantity of heroin(gm/day) } \\
\text { Range } \\
\text { Mean } \pm \text { SD }\end{array}$ & $\begin{array}{c}18-30 \\
24.8 \pm 3.4 \\
\\
2-23 \\
8.5 \pm 5.4 \\
\\
0.25-3 \\
1.0 \pm 0.7\end{array}$ \\
\hline
\end{tabular}

$\mathrm{N}$ : Number of subjects

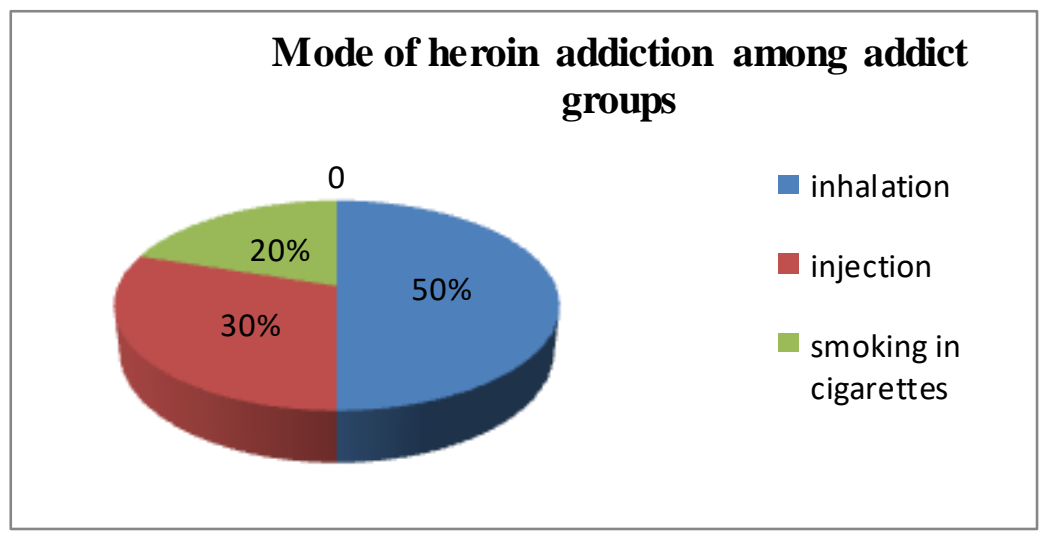

Figure 1. Mode of heroin addiction among addict groups

Sexual functions assessment results showed that there were highly statistically significant differences between addiction (II, III) groups and control (I) group in all domains of International Index of Erectile Function $(\mathrm{P}<0.0001)$. There was significant difference between both addiction groups (II) and (III) $(\mathrm{P}<0.05)($ Table 3).On examining the linear correlation between International Index of Erectile Function domain scores, heroin period and heroin quantity showed statistically significant negative correlation between all domains of International Index of Erectile Functionand heroin period, while there was statistically significant negative correlation between orgasmic function, intercourse satisfaction, overall satisfaction and heroin quantity

(Table 
Table 3. Statistical analysis of Sexual functions assessment among the studied groups (Student $\mathrm{t}$ test).

\begin{tabular}{|c|c|c|c|c|c|c|c|c|c|}
\hline & $\begin{array}{l}\text { Control group } \\
\text { I } \\
(\mathrm{N}=90)\end{array}$ & $\begin{array}{l}\text { Addiction } \\
\text { group } \\
\text { II } \\
(\mathbf{N}=45)\end{array}$ & $P$ value & $\begin{array}{l}\text { Control } \\
\text { group } \\
\text { I } \\
(\mathrm{N}=90)\end{array}$ & $\begin{array}{l}\text { Addiction group } \\
\text { III } \\
(\mathrm{N}=45)\end{array}$ & $P$ value & $\begin{array}{l}\text { Addiction group } \\
\text { II } \\
(\mathrm{N}=\mathbf{4 5})\end{array}$ & $\begin{array}{l}\text { Addiction group } \\
\text { III } \\
(\mathrm{N}=45)\end{array}$ & $P$ value \\
\hline $\begin{array}{l}\text { 1-Erectile function } \\
\text { 2-Orgasmic } \\
\text { function } \\
\text { 3-Sexual desire } \\
\text { 4-Intercourse } \\
\text { satisfaction } \\
\text { 5-Overall } \\
\text { satisfaction }\end{array}$ & $\begin{array}{l}25.1 \pm 8.2 \\
8.5 \pm 2.7 \\
8.9 \pm 1.9 \\
14.5 \pm 4.1 \\
9.1 \pm 2.9\end{array}$ & $\begin{array}{l}17.6 \pm 6.1 \\
6.1 \pm 1.6 \\
5.3 \pm 1.5 \\
8.2 \pm 2.1 \\
6.7 \pm 2.2\end{array}$ & $\begin{array}{l}<0.0001 * \\
<0.0001 * \\
<0.0001 * \\
<0.0001 * \\
<0.0001 *\end{array}$ & $\begin{array}{l}25.1 \pm 8.2 \\
8.5 \pm 2.7 \\
8.9 \pm 1.9 \\
14.5 \pm 4.1 \\
9.1 \pm 2.9\end{array}$ & $\begin{array}{l}20.2 \pm 5.4 \\
6.9 \pm 1.5 \\
6.1 \pm 1.6 \\
9.2 \pm 2.5 \\
7.4 \pm 2.4\end{array}$ & $\begin{array}{l}0.0004^{*} \\
0.0003^{*} \\
<0.0001^{*} \\
<0.0001^{*} \\
0.0009^{*}\end{array}$ & $\begin{array}{l}17.6 \pm 6.1 \\
6.1 \pm 1.6 \\
5.3 \pm 1.5 \\
8.2 \pm 2.1 \\
6.7 \pm 2.2\end{array}$ & $\begin{array}{l}20.2 \pm 5.4 \\
6.8 \pm 1.5 \\
6.1 \pm 1.6 \\
9.2 \pm 2.5 \\
7.4 \pm 2.4\end{array}$ & $\begin{array}{l}0.03^{*} \\
0.02^{*} \\
0.02 * \\
0.04^{*} \\
0.1\end{array}$ \\
\hline
\end{tabular}

$\mathrm{N}$ : Number of subjects.

Data are expressed as mean $\pm \mathrm{SD}$.

*Significant.

Table 4. Correlation between heroin period, heroin quantity and sexual functions

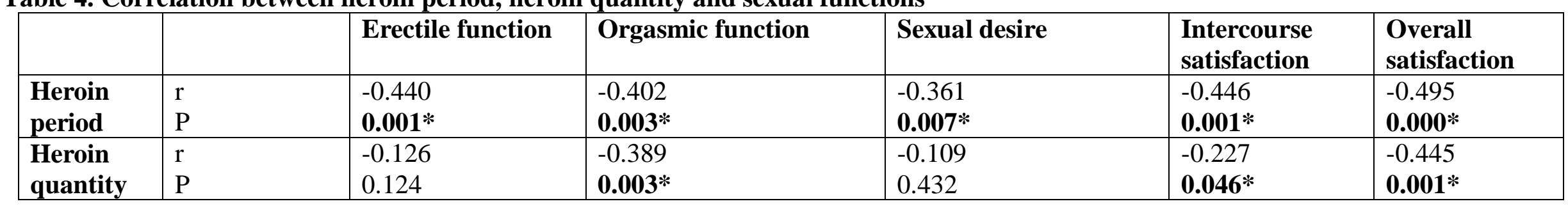

r: Correlation factor.

*Significant

\section{Hormonal assay results:}

The mean values of testosterone, FSH and LH levels in both addiction groups (II) and (III) were significantly lower than control group $(\mathrm{P}<0.0001)$. While, the levels of testosterone, FSH and LH were significantly higher in addiction group III (follow up group) as compared to addiction group II (initiation group) $(\mathrm{P}<0.05)$ (Table 5). 
Table 5. Statistical analysis of Sex hormones levels among the studied groups (Student $t$ test).

\begin{tabular}{|c|c|c|c|c|c|c|c|c|c|}
\hline & $\begin{array}{c}\text { Control } \\
\text { group } \\
\text { I } \\
(\mathbf{N}=\mathbf{9 0})\end{array}$ & $\begin{array}{l}\text { Addiction } \\
\text { group } \\
\text { II } \\
(\mathbf{N}=\mathbf{4 5})\end{array}$ & $P$ value & $\begin{array}{c}\text { Control } \\
\text { group } \\
\text { I } \\
(\mathbf{N}=90)\end{array}$ & $\begin{array}{l}\text { Addiction } \\
\text { group } \\
\text { III } \\
(\mathbf{N}=\mathbf{4 5})\end{array}$ & $P$ value & $\begin{array}{l}\text { Addiction } \\
\text { group } \\
\text { II } \\
(\mathbf{N}=\mathbf{4 5})\end{array}$ & $\begin{array}{l}\text { Addiction } \\
\text { group } \\
\text { III } \\
(\mathbf{N}=\mathbf{4 5})\end{array}$ & $P$ value \\
\hline Testosterone (ng/ml) & $5.46 \pm 1.8$ & $2.51 \pm 0.82$ & $<0.0001 *$ & $5.46 \pm 1.8$ & $2.9 \pm 0.81$ & $<0.0001 *$ & $2.51 \pm 0.82$ & $2.9 \pm 0.81$ & $\mathbf{0 . 0 3}$ \\
\hline FSH(mIU/ml) & $4.6 \pm 1.3$ & $2.8 \pm 0.98$ & $<0.0001 *$ & $4.6 \pm 1.3$ & $3.3 \pm .99$ & $<0.0001 *$ & $2.8 \pm 0.98$ & $3.3 \pm .99$ & 0.02 \\
\hline LH(mIU/ml) & $5.6 \pm 1.5$ & $3.9 \pm 1.2$ & $<0.0001 *$ & $5.6 \pm 1.5$ & $4.5 \pm 1.3$ & $<0.0001 *$ & $3.9 \pm 1.2$ & $4.5 \pm 1.3$ & 0.025 \\
\hline
\end{tabular}

N: Number of subjects.

Data are expressed as mean \pm SD .

*Significant.

\section{Gene expression analysis results}

The relative expression of CYP19 in the peripheral blood of heroin addictionsubgroups (initiation of drug withdrawal therapy (II) and 6-months follow up(III) was significantly higher when compared to control group $(\mathrm{P}<0.0001)$. However, the level of FSH-B and LH-B were significantly lower than controls
$(\mathrm{P}<0.0001)$. On comparing the both groups of heroin addiction (II) and (III), the relative gene expression of CYP19 was significantly lowered and the level of FSH-B and LH-B were significantly higher in follow up group than initiation group $(\mathrm{P}<0.05)$ (Table 6).

Table 6: Statistical analysis of Gene expression among the studied groups among the studied groups (Student $t$ test).

\begin{tabular}{|c|c|c|c|c|c|c|c|c|c|}
\hline & $\begin{array}{c}\text { Control } \\
\text { group } \\
\text { I } \\
(\mathbf{N}=90)\end{array}$ & $\begin{array}{l}\text { Addiction } \\
\text { group } \\
\text { II } \\
(\mathbf{N}=\mathbf{4 5})\end{array}$ & $P$ value & $\begin{array}{c}\text { Control } \\
\text { group } \\
\text { I } \\
(\mathbf{N}=90)\end{array}$ & $\begin{array}{l}\text { Addiction } \\
\text { group } \\
\text { III } \\
(\mathbf{N}=45)\end{array}$ & $P$ value & $\begin{array}{l}\text { Addiction } \\
\text { group } \\
\text { II } \\
(\mathbf{N}=\mathbf{4 5})\end{array}$ & $\begin{array}{l}\text { Addiction } \\
\text { group } \\
\text { III } \\
(\mathbf{N}=\mathbf{4 5})\end{array}$ & $\begin{array}{c}\mathbf{P} \\
\text { value }\end{array}$ \\
\hline CYP19 & $1.35 \pm 0.02$ & $6.12 \pm 0.47$ & $<0.0001 *$ & $1.35 \pm 0.02$ & $5.09 \pm 0.07$ & $<0.0001 *$ & $6.12 \pm 0.47$ & $5.09 \pm 0.07$ & 0.03* \\
\hline FSH-B & $1.2 \pm 0.01$ & $0.58 \pm 0.08$ & $<0.0001^{*}$ & $1.2 \pm 0.01$ & $0.79 \pm 0.05$ & $<0.0001 *$ & $0.58 \pm 0.08$ & $0.79 \pm 0.05$ & $0.02 *$ \\
\hline LH-B & $1.21 \pm 0.05$ & $0.54 \pm 0.09$ & $<0.0001 *$ & $1.21 \pm 0.05$ & $0.69 \pm 0.06$ & $<0.0001 *$ & $0.54 \pm 0.09$ & $0.69 \pm 0.06$ & $0.02 *$ \\
\hline
\end{tabular}

CYP19: Cytochrome 19

Follicle stimulating hormone related gene FSH-B. Luteinizing Hormone related gene LH-B.
$\mathrm{N}$ : Number of subjects.

Data are expressed as mean $\pm \mathrm{SD}$.

*Significant 


\section{DISCUSSION}

Addiction is the most critical problem in various population all over the world. In spite of spreading of various illicit drugs abuse, Heroin remain the most popular drug in most areas. Sexual activity may be affected among drug abusers, especially for who are seeking childbearing.

In this study, 180 adult males swere enrolled, divided into 2 groups (Control (I) and Heroin addiction groups). The age of addiction group averaged (33.6 \pm 6.5$)$ years old (range from 2348) years, while control group averaged (32.8 \pm 6.2 ) years of age (range from 20-46) years of age with no statistical difference between them. This is consistent with (Cioe et al.,2010; Bang-Ping,2009) as their participants were within this range of age. It was reported that the prevalence rate of erectile and sexual dysfunction in men younger than 40 years old was $5 \%$, and this percentage was as high as $52 \%$ in men over the age of 50 (Grover et al., 2006; Selvin et al., 2007) so, the following sexual function variables: Erectile function, Orgasmic function, Sexual desire, Intercourse satisfaction and Overall satisfaction were related to the age of participants in our study.

In the present work, sexual functions and the associated factors of sexual dysfunction among heroin addict males who attend psychiatric outpatient clinic at Zagazig university hospitals were assessed, the results of heroin addiction history and sexual function assessment revealed that the sexual dysfunction was significantly high among heroin addiction groups II and III including decrease erectile function, orgasm, sexual desire and intercourse satisfaction and the sexual dysfunction was related to the heroin period abuse and heroin quantity. These results are consistent with Bang-Ping, (2009) in a study on Illicit drug abusers of heroin followed by amphetamine and MDMA (Ecstasy) monousers in drug abstention and treatment center in Taiwan who reported that erectile dysfunction, reduction in sexual desire, and increased ejaculation latency were most commonly in heroin users. Other study on opioid users who presented to a primary care program for buprenorphine therapy in Providence, USA, showed erectile dysfunction is highly prevalent among males abusing opioids (Cioe et al.,2010). Studies on opioid substitution treatment receiving subjects in drugs treatment center in Italy and Australia respectively, who reported high prevalence of erectile dysfunction, related to hypogonadism and depression among men receiving methadone or buprenorphine maintenance treatment (Hallinan et al.,2008; Quaglio et al., 2008). The reduction of erectile function and sexual desire may be attributed to heroin induced reduction of testosterone levels and hypogonadism (Gore et al., 2005). There are several factors that affect sexual function such as health, lifestyle, emotion, sexual experience, interpersonal relation, hormone, medication, and illicit drug abuse (Levine, 2003).

The current study evaluated the effect of illicit heroin abuse on sex hormones related genes and sex hormones profile of heroin addict males. The results showed significant up regulation of CYP 19 gene and significant down regulation of FSH-B and LH-B genes in the blood of addiction groups II and III as compared to control group. On the other hand, there was significant difference between addiction group II subjects who just initiated withdrawal therapy and addiction group III who followed up for 6 months.

No studies have been conducted to estimate or to follow up sex hormones related genes (CYP19, FSH-B, LH-B) in human blood as indicator for affection of sexual function in heroin addicts at the initiation of heroin withdrawal.

Cytochrome 19 gene which encodes aromatase enzyme, is a solitary gene located on chromosome 15q21.1 in humans (member of the cytochrome P450 gene family) (Sebastian and Bulun,2001). Aromatase enzyme is responsible for the irreversible conversion of androgens into estrogens and expressed in endoplasmic reticulum of various tissues as placenta (Harada et al., 2003), some areas of the brain (Balthazart et al., 2003), gonads 
(Carreau et al., 2004), and peripheral blood (Vottero et al., 2006).

The pituitary glycoprotein hormone family consists of identical alpha subunit and a hormone-specific beta subunit. The betasubunit is a mature protein which is encoded by the FSH-B and LH-B genes. The FSH-B and LH-B genes lengths are 4262 (bp) and 1111(bp) and located at chromosomes $11 \mathrm{p} 13$ and 19q13.32; respectively (Nagirnaja et al., 2010).

Some studies attributed the expression of CYP 19 gene to aromatization of testosterone to estrogen (DeRondeet al., 2005). Others reported increased estrogen levels after testosterone administration for men subjects as a result of increased aromatase gene expression (Maffei et al., 2004; Rochira et al.,2005).

The down regulation of FSH-B and LH-B genes expression might be affected by peripheral testosterone reduction induced by chronic opioid addiction and consecutively production and release of FSH and LH from pituitary gland (Katz, 2005).

The sex hormone profile showed reduction of FSH, LH and testosterone in the serum of addiction groups II and III as compared to control group. On the other hand, there was significant difference between addiction group II subjects who just initiated withdrawal therapy and addiction group III who followed up for 6 months. The current results are in accordance with the results of Finch et al. (2000) who reported Hypogonadotrophic hypogonadism in the form of reduction in FSH, $\mathrm{LH}$, and testosterone in patients treated with intrathecal opioids for treatment of chronic nonmalignant pain in Western Australian Pain Management Centre. And Hejazian et al (2007) who showed that the serum testosterone in opium addicts who presented to drugs treatment centers in Iran were decreased significantly compared to the controls. This reduction was directly proportional to the duration of opium usage. The LH and FSH level in opium addicts showed also significant reduction compared to the controls.
Gonadotropine hormones (FSH and LH) are functionally related hormones regulating the reproductive function centrally. In males; LH stimulates testosterone production in Leydig cells. While FSH promotes proliferation of sertoli cell that help spermatogenesis (Plant and Marshall, 2001).

Moshtaghi et al., (2005) suggested the reduction of gonadotropine hormones as a result of suppression of gonadotropine releasing hormone $(\mathrm{GnRH})$ from hypothalamus due to increased prolactin levels in opioid addicts. Others suggested that gonadotropine releasing cells are directly affected by opioid action on $\mathrm{mu}$ and kappa receptors (SokolowskaMikolajczyk et al., 2005).

Furthermore, the reduction of testosterone hormone attributed to blocking its synthesis from testicular Sertoli cells by peripheral action of opioid directly (Vuong et al.,2010) or by increased aromatization of testosterone to estradiol (Ceccarelli et al., 2006).

\section{Conclusion}

Regarding the current study results, it was concluded that heroin addiction produced a matter of sexual dysfunction in domains of erectile function, orgasm, sexual desire, intercourse satisfaction and reduction of sex hormones (FSH, LH and testosterone) secondary to affection of hormone related genes (down regulation of FSH-B, LH-B and up regulation of CYP 19). The results of sexual dysfunction domains, sex hormones and sex hormones related genes expression were improved in the group of heroin discontinuation for 6 months. It is recommended to increase the period of follow up of heroin addicts as complete improvement may occur.

Ethical aspect and administrative approach:

The research protocol was approved by Ethics Committee of Faculty of Medicine, Zagazig University, Egypt and the reference number is ZU- IRB: 4101.Before carrying out the study, the necessary official permission was taken from hospital manager and the head of Zagazig University Hospitals and the head of the psychiatric department. An informed written consent was obtained from studied groups. 
They were reassured about the confidentiality of any obtained information and that the results would be used for the purpose of research.

\section{Acknowledgments}

We would like to thank all participants in this study for their cooperation, also the hospital management for their support in achieving our work.

\section{REFERENCES}

Balthazart J, Baillien M, Charlier TD, Cornil CA and Ball GF. Multiple mechanisms control brain aromatase activity at the genomic and non-genomic level. Journal of Steroid Biochemistry and Molecular Biology2003 ; 86: 367-379.

Bang-Ping J. Sexual dysfunction in men who abuse illicit drugs: a preliminary report. J Sex Med 2009; 6:10721080 .

Craparo, R M. Significance level. In Salkind, Neil J. Encyclopedia of Measurement and Statistics. $3^{\text {rd }}$ edition, 2007, Thousand Oaks, CA: SAGE Publications. PP. 889891.

Carreau S, Bourguiba S, Lambard S, Silandre D and Delalande C. The promoter(s) of the aromatase gene in male testicular cells. Reproductive Biology 2004;4: 2334. https://www.researchgate.net/.../8608558 Accessed 26 July 2017

Ceccarelli I, De Padova AM, Fiorenzani $P$ et al. Single opioid administration modifies gonadal steroids in both CNS and plasma of male rats. Neuroscience 2006;140: 929-937.

Cioe PA. FriedmannP D, Stein $M$ D. Erectile Dysfunction in Opioid Users: Lack of Association with Serum Testosterone.J Addict Dis. 2010; 29(4): 455-460.

Cummins T and Miller S. The effects of drug abuse on sexual functioning. In: Handbook of clinical sexuality for mental health professionals Levine SB (ed), $2^{\text {nd }}$ edition, 2003, New York, Brunner-Routledge:443-456.

De Ronde W, A. Hofman Pols HA, de Jong FH. A direct approach to the estimation of the origin of oestrogens and androgens in elderly men by comparison with hormone levels in postmenopausal women. Eur J Endocrinol 2005; 15: 2261-2268.

Finch PM, Robers L, Price L, Hadlow NC, Pullan PT. Hypogonadism in patients treated with intrathecal morphine. Clin J Pain 2000; 16: 251-254.

Gore JL, Swerdloff RS, Rajfer J. Androgen deficiency in the etiology and treatment of erectile dysfunction. Urol Clin North Am 2005; 32:457-68.

Grover SA, Lowensteyn I, Kaouache M, Marchand S, Coupal L, DeCarolis E, Zoccoli J et al. The prevalence of erectile dysfunction in the primary care setting: importance of risk factors for diabetes and vascular disease. Arch Intern Med 2006; 166:213-9.

Hallinan R, Byrne A, Agho K, McMahon C, Tynan P, Attia J. Erectile dysfunction in men receiving methadone and buprenorphine maintenance treatment. J Sex Med 2008; 5:684-92.

Harada N, Yoshimura $\mathbf{N}$ and Honda $\mathbf{S}$. Unique regulation of expression of human aromatase in the placenta. Journal of Steroid Biochemistry and Molecular Biology 2003; 86: 327-334.

Hejazian S.H, Dashti M.H Rafati, A. The effect of opium on serum LH, FSH and testosterone concentration in addicted men. Iranian Journal of Reproductive Medicine2007; 5(1): 35-38. https://www.bioline.org.br/pdf?rm07007Accessed 11 July 2017

Katz N. The impact of opioids on the endocrine system, Pain Manag2005; 19:1-6.

Langham S, Wright A, Kenworthy J, Grieve R, Dunlop WCN. Cost-Effectiveness of Take-Home Naloxone for the Prevention of Overdose Fatalities among Heroin Users in the United Kingdom. Value Health. 2018; 21(4):407-415.

Levine SB. The nature of sexual desire: A clinician's perspective. Arch Sex Behav2003; 32:279-85.

Livak KJ. Analysis of relative gene expression data using real-time quantitative pcr and the 2- $\Delta \Delta \mathrm{CT}$ method. Methods 2001; 25: 402-408.

Maffei L, Murata Y, Rochira V, Tubert G, Aranda C, Vazquez M, Clyne CD, et al. Dysmetabolic syndrome in a man with a novel mutation of the aromatase gene: effects of testosterone, alendronate, and estradiol treatment. Journal of Clinical Endocrinology and Metabolism 2004; 89: 61-70.

Malik SA1, Khan C, Jabbar A, Iqbal A. Heroin addiction and sex hormones in males.J Pak Med Assoc1992;42(9):210-2.

Mehtry V, Kiran Kumar P.K, Shetty N, Bhandary S, Adappa K, Soans S, Maben E, et al. Substance use and Sexual Dysfunction. Journal of Evolution of Medical and Dental Sciences 2013; 2 (44): 8620-8628.

Moshtaghi-Kashanian GR, Esmaeeli F, Dabiri S. Enhanced prolactin levels in opium smokers. Addict Biol2005; 10: 345- 349.

Nagirnaja L, Rull K, UuskülaLet al. Genomics and genetics of gonadotropin beta-subunit genes: Unique $F S H B$ and duplicated $L H B / C G B$ loci.Mol Cell Endocrinol2010; 329:4

16.https://www.ncbi.nlm.nih.gov/pmc/articles/PMC29543 07/

National Institute of Drug Abuse Advancing addiction science: Heroin. Government Office. Washington DC,2018.

https://www.drugabuse.gov/publications/heroin/what-aretreatments-heroin-use-disorder Accessed 16 June 2018.

Nestler EJ. Reflections on: A general role for adaptations in G-Proteins and the cyclic AMP system in mediating the chronic actions of morphine and cocaine on neuronal function. Brain Res. 2015;1645: 71-74. 
Plant TM, MarshallGR. The functional significance of $\mathrm{FSH}$ in spermatogenesis and the control of its secretion in male primates. Endocr Rev 2001; 22: 764-786.

Quaglio G, Lugoboni F, Pattaro C, Melara B, Mezzelani P, Des Jarlais DC. Erectile dysfunction in male heroin users, receiving methadone and buprenorphine maintenance treatment. Drug Alcohol Depend2008; 94:12-8.

Rochira V, Granata AR, Madeo B, Zirilli L, Rossi G \& Carani C. Estrogens in males: what have we learned in the last 10 years? Asian Journal of Andrology 2005; 7:3 20.

Rosen RC, Riley A, Wagner G, Osterloh IH, Kirkpatrick J, Mishra A. The international index of erectile function (IIEF) a multidimensional scale for assessment of erectile dysfunction. Urology 1997; 49(6):822-30

Sebastian S, Bulun SE. Genetics of endocrine disease. A highly complex organization of the regulatory region of the human CYP19 (aromatase) gene revealed by the human genome project. Journal of Clinical Endocrinology and Metabolism 2001; 86: 4600-4602.

Selvin E, Burnett AL, Platz EA. Prevalence and risk factors for erectile dysfunction in the US. Am J Med 2007; 120:151-157.
Sokolowska-Mikolajczyk M, Socha M, Mikolajczyk T, Chyb J, Szymacha J, Epler P. Differential effects of morphine and naltrexone on the in vitro LH secretion from male and female carp pituitary gland. Comp Biochem Physiol C Toxicol Pharmacol 2005; 141: 325331.

Trajanovska AS, Vujovic V, Ignjatova L, JanicevicIvanovska D, Cibisev A. Sexual dysfunction as a side effect of hyperprolactinemia in methadone maintenance therapy. Med Arch 2013; 67:48-50.

Uchtenhagen A A. Heroin maintenance treatment: from idea to research to practice. Drug and Alcohol Review 2011; 30 (2): 130-137.

Vottero, A Rochira V, Capelletti M, Viani, I Zirilli, L Neri, T M Carani, C Bernasconi $S$ and Ghizzoni L. Aromatase is differentially expressed in peripheral blood leukocytes from children, and adult female and male subjects. European Journal of Endocrinology 2006;154: 425-431.

Vuong C, Van Uum SHM, O'Dell LE et al. The Effects of opioids and opioid Analogs on Animal and Human Endocrine Systems. Endocr Rev2010;31(1):98-132. 
ارتباط دلائل جينات الهرمونات الجنسيه والوظائف الجنسيه بين ذكور مدمنون الهروين بمستثفيات جامعه الزقازيق بمصر

لقد اصبح ادمان المخدرات من المشكلات الكبيره حول العالم مما له من العديد من اللآثار السلبيه على الصحه ـ يوجد العديد من التقاير الخاصه بمشاكل الصحه الجنسيه مؤثره على نسب الهرمونات لها ارتباط قوى بادمان الهروين لذلك كان من اهداف هذة الدراسه هو در اسه علاقه الارتباط بين العجز الجنسى و اضطر ابات الهرومات الجنسيه وكذلك الجينات المسئوله عن الهرمونات الجنسيه فى حالات الادمان من الرجال المترددين على العيادات الخارجيه لعلاج الادمان بمستشفيات جامعه الزقازيق بمصر . . طرق البحث: تقييم حالات العجز الجنسي عن طريق عمل استبيانات وتحديد نسب المؤشر الدولى للانتصاب بين 180 مشارك منهم 90 حاله ادمان و90 مشارك غير مدمن حيث تم تقيم حالات الادمان الى مجموعتين : المجموعه الاولى 45 حاله فى بدايه العلاج و المجمو عه الثانيه 45 حاله قد مر على بدايه العلاج 6 شهور.تم سحب عينات الدم لتحليل كلا من الهرمونات و الجينات الجنسيه . النتائج: اظهرت نتائج الدراسه ان ادمان الهروين ادى الى زيادة وجود الجين المسئول عن تكوين الاسترديول بكثرة مما يؤثر بالسلب على هرمون الذكورة كما ادى نقص الجينات المسئوله عن هرمونات الغدة النخاميهما ادى الى نقص الهرمونات الجنسيه مما ادى الى نوع من العجز الجنسي بين حالات ادمان الهروين. الاستتناج: اثتتت الدر اسه انه يوجد ارتباط بين ادمان الهروين و العجز الجنسى الواضح من نتائج الاستبيانات وتأثر الجينات الجنسيه مما ادى اللى نقص الهرمونات واظهرت المجموعه التى انقطعت عن تعاطى الهروين لمدة 6 شهور تحسن جزىء كما نقترح اطاله فنرة المتابعه لحالات ادمان الهروين الخاضعه للعلاج و التى من المحتمل ان تظهر تحسن كامل. 


\section{Heroin addiction questionnaire}

\section{Socio demographic data:}

*Name:

*Education: 1- illiterate 2-read and write

*Occupation: 1-un employee 2-skilled worker

*Age:

3-primary 4-secondary 5-university

* Income: 1-Unsufficient 2-Sufficient 3-Sufficient and more

*Residence: 1- Urban 2-rural

* Marital status: 1-single 2-married 3-divorced 4-widow

If answer rather than single

Have children: 1-yes 2-no

If having children, the oldest aged:

**Cigarette smoking status: 1-smoker 2-nonsmoker

**Do you suffer from any chronic disease? yes no

If yes (mention):

Heroin addiction history

**Mode of heroin addiction: 1- inhalation 2-smoking in cigarettes 3-both 4-others

$* *$ the age of first heroin use

**Period of heroin abuse (years):

**Quantity of heroin abuse (gm/day):

Sexual history (International index of erectile function) (ILEF)

1. Over the past 4 weeks, how often were you able to get an erection during sexual activity?

0 No sexual activity

0 Almost always or always

0 Most times (much more than half the time)

0 Sometimes (about half the time)

0 A few times (much less than half the time)

0 Almost never or never

2. Over the past 4 weeks, when you had erections with sexual stimulation, how often were your erections hard enough for penetration?

0 No sexual stimulation

0 Almost always or always

0 Most times (much more than half the time)

0 Sometimes (about half the time)

0 A few times (much less than half the time)

0 Almost never or never

Questions 3, 4 and 5 will ask about erections you may have had during sexual intercourse.

3. Over the past 4 weeks, when you attempted sexual intercourse, how often were you able to penetrate (enter) your partner?

0 Did not attempt intercourse

0 Almost always or always

0 Most times (much more than half the time)

0 Sometimes (about half the time)

0 A few times (much less than half the time)

0 Almost never or never

4. Over the past 4 weeks, during sexual intercourse, how often were you able to maintain your erection after you had penetrated (entered) your partner? 
0 Did not attempt intercourse

0 Almost always or always

0 Most times (much more than half the time)

0 Sometimes (about half the time)

0 A few times (much less than half the time)

0 Almost never or never

5. Over the past 4 weeks, during sexual intercourse, how difficult was it to maintain your erection to completion of intercourse?

0 Did not attempt intercourse

0 Almost always or always

0 Most times (much more than half the time)

0 Sometimes (about half the time) $0 \mathrm{~A}$ few times (much less than half the time)

0 Almost never or never

6. Over the past 4 weeks, how many times have you attempted sexual intercourse?

0 No attempts

0 1-2 attempts

0 3-4 attempts

0 5-6 attempts

0 7-10 attempts

011 or more attempts

7. Over the past 4 weeks, when you attempted sexual intercourse how often was it satisfactory for you?

0 Did not attempt intercourse

0 Almost always or always

0 Most times (much more than half the time)

0 Sometimes (about half the time)

0 A few times (much less than half the time)

0 Almost never or never

8. Over the past 4 weeks, how much have you enjoyed sexual intercourse?

0 No intercourse

0 Very highly enjoyable

0 Highly enjoyable

0 Fairly enjoyable

0 Not very enjoyable

0 Not enjoyable

9. Over the past 4 weeks, when you had sexual stimulation or intercourse how often did you ejaculate?

0 Did not attempt intercourse

0 Almost always or always

0 Most times (more than half the time)

0 Sometimes (about half the time)

0 A few times (much less than half the time)

0 Almost never or never

10. Over the past 4 weeks, when you had sexual stimulation or intercourse how often did you have the feeling of orgasm or climax (with or without ejaculation)?

0 No sexual stimulation or intercourse

0 Almost always or always

0 Most times (much more than half the time)

0 Sometimes (about half the time) 
0 A few times (much less than half the time)

0 Almost never or never

Questions 11 and 12 ask about sexual desire. Let's define sexual desire as a feeling that may include wanting to have a sexual experience (for example, masturbation or intercourse), thinking about having sex or feeling frustrated due to a lack of sex.

11. Over the past 4 weeks, how often have you felt sexual desire?

0 Almost always or always

0 Most times (much more than half the time)

0 Sometimes (about half the time)

0 A few times (much less than half the time)

0 Almost never or never

12. Over the past 4 weeks, how would you rate your level of sexual desire?

0 Very high

0 High

0 Moderate

0 Low

0 Very low or none at all

13. Over the past 4 weeks, how satisfied have you been with you overall sex life?

0 Very satisfied

0 Moderately satisfied

0 About equally satisfied and dissatisfied

0 Moderately dissatisfied

0 Very dissatisfied

14. Over the past 4 weeks, how satisfied have you been with your sexual relationship with your partner?

0 Very satisfied

0 Moderately satisfied

0 About equally satisfied and dissatisfied

0 Moderately dissatisfied

0 Very dissatisfied

15. Over the past 4 weeks, how do you rate your confidence that you can get and keep your erection?

0 Very high

0 High

0 Moderate

0 Low

0 Very low

\section{Scoring Algorithm for IIEF}

All items are scored in 5 domains as follows:

$\begin{array}{llll}\text { Domain } & \text { Items } & \text { Range } & \begin{array}{l}\text { Score Max } \\ \text { Score }\end{array} \\ \text { Erectile Function } & 1,2,3,4,5,15 & 0-5 & 30 \\ \text { Orgasmic Function } & 9,10 & 0-5 & 10 \\ \text { Sexual Desire } & 11,12 & 0-5 & 10 \\ \text { Intercourse Satisfaction } & 6,7,8 & 0-5 & 15 \\ \text { Overall Satisfaction } & 13,14 & 0-5 & 10 \\ \text { Clinical Interpretation } & & \end{array}$


I. Erectile function total scores can be interpreted as follows:

Score

0-6

$7-12$

$13-18$

$19-24$

25-30

\section{Interpretation}

Severe dysfunction

Moderate dysfunction

Mild to moderate

dysfunction

Mild dysfunction

No dysfunction

II. Orgasmic function total scores can be interpreted as follows:

\section{Score}

$0-2$

$3-4$

$5-6$

$7-8$

9-10

\section{Interpretation}

Severe dysfunction

Moderate dysfunction

Mild to moderate

dysfunction

Mild dysfunction

No dysfunction

III. Sexual desire total scores can be interpreted as follows:

Score

0-2

3-4

$5-6$

$7-8$

\section{Interpretation}

Severe dysfunction

Moderate dysfunction

Mild to moderate

dysfunction

Mild dysfunction 
IV. Intercourse satisfaction total scores can be interpreted as follows:

\section{Score}

\section{Interpretation}

$0-3$

4-6

7-9

10-12

13-15
Severe dysfunction

Moderate dysfunction

Mild to moderate

dysfunction

V. Overall satisfaction total scores can be interpreted as follows:

Score

0-2

3-4

5-6

$7-8$

9-10

\section{Interpretation}

Severe dysfunction

Moderate dysfunction

Mild to moderate

dysfunction

Mild dysfunction

No dysfunction 